\title{
DAMPAK PERUBAHAN SOSIAL TERHADAP PENDIDIKAN
}

Oleh:

\author{
Dr. M. Syukri Azwar Lubis, MA \\ Email : Muhammadsyukri_azwar@yahoo.co.id \\ UIN Sumatera Utara.
}

\begin{abstract}
Abstrak
Perubahan sosial budaya merupakan sebuah gejala berubahnya struktur sosial dan pola budaya dalam kehidupan tatanan masyarakat. Perubahan sosial budaya merupakan gejala umum yang terjadi sepanjang masa dalam setiap masyarakat. Perubahan ini terjadi pula sesuai dengan kehendak, hakikat dan sifat dasar manusia yang selalu menginginkan perubahan. Sedangkan pendidikan adalah usaha sadar dan suatu bentuk dari seni dan budaya manusia yang terus berubah, berkembang dan sebagai alternatif yang paling rasional dan memungkinkan untuk melakukan suatu perubahan maupun perkembangan. Hubungan antara perubahan sosial dengan pendidikan adalah terjadinya perubahan pada struktur dan fungsi dalam sistem sosial dan termasuk di dalamnya adalah pendidikan, sebab karena pendidikan ada dalam masyarakat, baik itu pendidikan formal, informal maupun non formal.
\end{abstract}

Keyword: Dampak, perubahan sosial dan pendidikan

\section{Pendahuluan}

Setiap manusia selama hidup dapat dipastikan akan mengalami banyak sekali peru ahan-perubahan. Perubahan dapat berupa yang menarik dan perubahan yang tidak menarik. Ada pula perubahan yang pengaruhnya masih terbatas dan ada pula yang luas serta perubahan yang bergerak secara lambat dan perlahan. Tidak ada kehidupan masyarakat yang terhenti pada satu titik tertentu sepanjang masa. Perubahan-perubahan tersebut dapat berupa nilai sosial, norma sosial, pola perilaku masyarakat, atau lembaga lainnya. Oleh karena itu menurut William F. Oqbun sebagaimana dinukil oleh Soerjono ia berpendapat bahwasanya ruang lingkup perubahan sosial meliputi unsur kebudayaan, baik material, maupun immaterial. ${ }^{1}$

Kehidupan adalah sesuatu yang sangat dan teramat dinamis, dengan demikian kehidupan akan senantiasa mengalami perubahan maka manusia pun

${ }^{1}$ Soerjono Sokenato, Sosiologi Suatu Pengantar, cet. 5 (Jakarta: Raja Grafindo Persada, 2003), h. 304 
juga akan mengalami hal yang sama mengalami perubahan pada titik-titik tertentu, baik manusia sebagai makhluk individu maupun manusia sebagai makhluk dalam masyarakat. Dalam perubahan yang terjadi pada masyarakat bisa juga terjadi dalam pola perilaku individu maupun organisasi, perubahan dalam norma maupun dalam organisasi, perubahan alam norma sosial. Interaksi yang di dalamnya terdapat pendidikan.

Oleh karena kehidupan itu dinamis, maka perubahan yang terjadi dalam kehidupan manusia merupakan sebuah fenomena yang lazim yang terjadi dalam kehidupan yang pengaruhnya bahkan bisa menjalar dan merambah kebagian yang sesungguhya teramat canggih dan modern dalam kehidupan manusia, bahkan sampai kebelahan dunia lain dengan cepat dan efektif karena didukung oleh kemajuan komunikasi yang canggih dan modern. Penemuan-penemuan baru dibidang teknologi tanpa kita sadari juga akan sangat mempengaruhi perubahan sosial yang juga akan berdampak sangat serius bagi pendidikan.

Suatu perubahan sosial yang terjadi sekecil apapun mungkin akan berkibat pada strukur kehidupan masyarakat yang lainnya, misalnya pada perubahan gaya berpakaian akan menghasilkan akibat pada ekonomi masyarakat, sebab suatu model yang trend akan senantiasa diikuti oleh masyarakat yang menyenangi model-model terbaru. sama halnya dampak dari perubahan sosial aka berakibat pada pendidikan dengan sangat serius.

\section{A. Pengertian dan Proses Perubahan Sosial Budaya}

Menurut kamus besar Bahasa Indonesia perubahan berarti hal, keadaan berubah, peralihan, pertukaran. ${ }^{2}$ Sedangkan sosial adalah hal yang berkenan dengan masyarakat. ${ }^{3}$ Perubahan sosial adalah berubahnya sebuah struktur atau susunan sosial kemasyarakatan dalam kehidupan masyarakat. Perubahan tersebut merupakan gejala umum yang terjadi sepanjang masa dalam setiap tatanan kehidupan bermasyarakat, perubahan ini juga terjadi sesuai hakikat dan sifat dasar manusia yang selalu menginginkan perubahan dari satu keadaaan kepada keadaan lainnya yang lebih baik. Kebosanan manusia adalah penyebab dari suatu perubahan, manusia sering kali tidak puas dan berusaha untuk mencari cara atau alternatif lainnya untuk menghilangkan kebosanannya dan menemukan cara baru

${ }^{2}$ Hasan Alwi, Kamus Besar Bahasa Indonesia (Jakarta: Balai Pustaka, 1990), h.981

${ }^{3}$ Ibid, h. 701 
yang jauh lebih menyenangkan, mudah dan murah. Bisa kita lihat bahwa revolusi teknologi transportasi yang demikian canggih hingga berakibat pada perubahan mobilitas manusia.

Perubahan sosial budaya adalah sebuah gejala berubahnya struktur sosial dan pola yang ada dalam suatu masyarakat. Perubahan sosial budaya merupakan gejala umum yang terjadi sesuai dengan hakikat dan sifat dasar manusia yang selalu ingin mengadakan perubahan. Hirscahman mengatakan bahwa kebosanan manusia sebenarnya merupakan penyebab dari perubahan. Perubahan sosial budaya terjadi karena beberapa faktor. Diantaranya komunikasi, cara, pola piker masyarakat, faktor internal dan faktor eksternal seperti: perubahan jumlah penduduk, penemuan baru, terjadinya konflik atau resolusi, bencana alam, perubahan iklim, peperangan dan pengaruh budaya lainnya.

Ruang lingkup perubahan sosial meliputi unsur-unsur budaya materil dan immaterial, artinya setiap unsur budaya masyarakat yang bersifat materil dan immaterial juga mempunyai kecenderungan terhadap perubahan. Berbeda dengan apa yang disampaikan oleh Kingleys Davis yang mengartikan perubahan sosial sebagai perubahan-perubahan yang terjadi dalam struktur dan fungsi masyarakat sehingga akan disebut sebagai perubahan sosial kalau tatanan dan fungsi masyarakat yang berubah. Sebagai contoh ketika muncul persatuan pekerja atau organisasi buruh yang di dalam masyarakat kapitalis menyebabkan perubahan hubungan antar pekerja dengan majikan yang kemudian berimplikasi juga pada berubahnya organisasi ekonomi atau bahkan politik.

Soerjono Soekamto dalam bukunya soiologi sebagai pengantar, mengutip pendapat Gillin tentang perubahan sosial sebagai suatu variasi dari sebuah cara hidup yang telah ada dan diterima dalam masyarakat, baik karena perubahanperubahan kondisi geografis, kebudayaan material, komposisi (susunan) penduduk, ideology maupun juga karena adanya difusi maupun penemuanpenemuan teknologi terbaru dalam suatu masyarakat. ${ }^{4}$ Jadi jika sebuah masyarakat mengadakan ataupun melakukan sebuah variasi atau cara lain dari kebiasaan yang sudah ada maka hal itu dapat dikatakan dengan sebuah perubahan. Konsep perubahan sosial merupakan sebuah fenomena yang teramat rumit, dalam

${ }^{4}$ Soerjono Soekamto, Sosiologi Sebagai Sebuah Pengantar ( Jakarta: Raja Grafindo Persada, 1990), h. 71 
arti menembus ke berbagai tingkat kehidupan sosial, jika kemudian muncul sebuah defenisi tentang perubahan sosial yang mencakup kepada seluruh aspek kehidupan sosial, maka hal tersebut teramat wajar susunan sosial, sistem sosial, dan organisasi masyarakat.

Dari pelbagai pendapat di atas dapat dikatakan bahwasanya perubahan sosial yaitu perubahan yang terjadi pada struktur dan fungsi sistem sosial, yang termasuk di dalamnya aspek kebudayaan juga nilai-nilai, norma, kebiasaan, kepercayaan, tradisi, sikap, maupun tingkah laku dalam suatu masyarakat, atau jika dibandingkan dengan keadaan dahulu, maka hal itu dapat dikatakan bahwa dalam struktur sosial masyarakat tersebut telah berubah.

Banyak yang berpendapat bahwa kecenderungan terjadinya suatu perubahan pada masyarakat merupakan fenomena yang wajar sebagai akibat dari pergaulan hidup dari pergaulan hidup dan banyak pakar yang mengemukakan pendapat bahwa perubahan sosial terjadi sebagai akibat adanya unsur-unsur yang mempertahankan keseimbangan dalam suatu masyarakat, seperti perubahan ekonomi, kebudayaan teknologi, politik, geografis dan lain sebagainya yang pada dasarnya bermuara pada kesimpulan bahwa perubahan merupakan suatu mata rantai kejadian yang melingkar dan tidak akan terputus.

Pada term norma perubahan sosial, maka jika norma adalah dasar dari keteraturan kehidupan sosial maka perubahan sosial yang merupakan perubahan dalam struktur masyarakat terjadi sebagai akibat dari perubahan dalam normanorma sosial tersebut, sehingga ketika norma dalam suatu struktur masyarakat telah berubah maka perubahan dalam masyarakat telah terjadi. ${ }^{5}$

Pendapat Pittirm A. Sorokin, yang meragukan kebenaran adanya lingkaran-lingkaran perubahan sosial, namun perubahan tetap ada dan yang paling penting lingkaran terjadinya gejala-gejala sosial harus dipelajari dan dengan jalan tersebut barulah dapat diperoleh suatu generalisasi tentang lingkaran perubahan sosial tersebut. ${ }^{6}$

Perubahan sosial budaya dapat dibedakan menjadi beberapa bentuk berikut ini:

${ }^{5}$ David Berry, Pokok-Pokok Pikiran Dalam Sosiologi, Terj. Paulus Wirutomo (Jakarta: Raja Grafindo Persada, 2003), h. 72

${ }^{6}$ Pittirm A. Sorokin dalam Soerjono, Ibid, h. 67 
1. Perubahan lambat dan perubahan cepat

Perubahan lambat disebut juga dengan evolusi. Perbuahan tersebut terjadi karena usaha-usaha masyarakat dalam menyesuaikan diri dengan keadaan lingkungan dan kondisi baru yang timbul sejalan dengan pertumbuhan masyarakat. Contoh perubahan evolusi adalah perubahan struktur masyarakat. Sebuah masyarakat pada masa tertentu bentuknya sangat sederhana namun karena masyarakat mengalami perkembangan maka bentuk yang sederhana tersebut akan berubah menjadi kompleks. Perubahan cepat disebut juga dengan revolusi, yaitu perubahan mengenai unsur-unsur kehidupan atau lembaga-lembaga kemasyarakatan yang berlangsung relatif cepat. Sering kali perubahan revolusi diawali dengan munculnya konflik atau ketegangan dalam masyarakat, ketegangan-ketegangan tersebut sulit dihindari bahkan semakin berkembang dan tidak dapat dikendalikan, revolusi adalah wujud perubahan sosial.

2. Perubahan kecil dan perubahan besar.

Perubahan kecil adalah perubahan yang terjadi pada unsur-unsur struktur sosial yang tidak membawa pengaruh langsung atau pengaruh yang berarti bagi masyarakat. Contoh perubahan kecil adalah perubahan mode rambut atau perubahan mode pakaian. Sebaliknya perubahan perubahan besar adalah perubahan yang terjadi pada unsur-unsur struktur sosial yang membawa perubahan langsung atau pengaruh yang sangat berarti bagi masyarakat. Contoh perubahan besar adalah dampak ledakan penduduk dan dampak industrialisasi bagi pola kehidupan masyarakat.

3. Perubahan yang dikehendaki atau direncanakan dan perubahan yang tidak dikehendaki atau tidak direncanakan.

Perubahan yang dikehendaki atau yang direncanakan terlebih dahulu yang telah diperkirakan atau direncanakan terlebih dahulu oleh pihak-pihak yang hendak melalukan perubahan di masyarakat. Pihak- pihak tersebut dinamakan dengan agen of change, yaitu seorang atau sekelompok orang yang mendapat keperacayaan masyarakat untuk memimpin satu atau lebih lembaga-lembaga kemasayarakatan yang bertujuan untuk mengubah tatanan sosial dan sistem sosial. Contoh perubahan yang dikehendaki adalah pelaksanaan pembangunan 
atau perubahan tatanan pemerintahan, misalnya perubahan tata pemerintahan orde baru menjadi tat pemerintahan orde reformasi. Perubahan yang tidak dikehendaki atau yang tidak direncanakan merupakan perubahan yang terjadi di luar jangkuan pengawasan masyarakat dan dapat menyebabkan timbulnya akibat-akibat sosial yang sangat tidak diharapkan. Contoh perubahan yang tidak dikehendaki atau tidak direncanakan adalah munculnya berbagai peristiwa kerusuhan menjelang masa peralihan tatanan orde baru ke orde reformasi.

Adapun arah perubahan sosial budaya, modernisasi dan pembangunan yang akan dituju oleh semua masyarakat bangsa dimanapun adalah meningkatkan kemakmuran yang diinginkan. Hidup di dunia sekarang dan masa depan menuntun penguasaan ilmu dan teknologi. Beberapa arah perubahan sosial budaya antara lain:

1. Konsumerisme yaitu pandangan hidup yang melihat bahwa lebih baik membeli produk barang dan jasa dari pada membuatnya sendiri.

2. Konsumtivismse yaitu mengkonsumsi barang dan jasa yang sebenarnya bukan merupakan keperluan hidupnya.

3. Hedonisme merupakan cara hidup bermewah-mewah untuk mengejar prestise atau gengsi tertentu.

4. Kesenjangan sosial dan ekonomi yang terjadi akibat adanya ketidakadilan dalam proses pembangunan, misalnya karena menekankan atau memprioritaskan daerah atau golongan sosial tertentu,

5. Munculnya berbagai perilaku menyimpang seperti kenakalan remaja, prostitusi dan sebagainya yang disebabkan oleh adanya keinginan untuk menyesuaiakan dengan taraf hidup, namun tidak didukung oleh kemampuan dan keterampilan yang memadai (demonstration effect). ${ }^{7}$

Selain arah tersebut di atas, beberapa teori yang mengubungkan pengembangan berbagai aspek atau unsur sosial budaya (nilai, institusi, dan kepribadian) dengan kebutuhan pembangunan yang pencapainnya akan memerlukan institusi pendidikan, diantaranya teori tersebut adalah sebagai berikut:

${ }^{7}$ Ibid, h. 89 
1. Teori orientasi, nilai sosial budaya yang dikembangkan oleh Kluckhohn dan Strodbeck yang mana dalam teori ini mengatakan bahwa dalam masyarakat terlihat dimana orientasi nilai-nilai yang menekankan pandangan waktu yang berorientasi kemasa depan, pandangan terhadap alam yang menekankan bahwa hukum alam dapat diketahui dan dikuasai, pandangan bahwa pekerja itu sesuatu yang dapat menimbulkan kerja yang lebih banyak, pandangan bahwa semua manusia itu sama, semuanya merupakan orientasi nilai yang telah membawa kemajuan.

2. Teori Pattern, menurut teori ini masyarakat modern adalah masyarakat yang menganut orientasi nilai yang menguatkan penilaian berdasarkan achievement atau keberhasilan atau prestasi bukan status.

3. Teori Alisyahbana yang menekankan pengembangan nilai teori dan nilai ekonomi yang merupakan aspek progresif dari suatu kebudayaan.

4. Selanjutnya teori Max Weber yang mana menurutnya panggilan hidup pekerjaan atau karir itu bukanlah suatu kondisi yang ditentukan oleh kelahiran, tetapi merupakkan pekerjaan yang dipilih dengan tepat dan dikerjakan dengan giat, harus dipilih sendiri dengan rasa tanggungjawab keagamaan.

5. Hegen, yang mengemukakan teori yang menjelaskan faktor-faktor yang bersifat motivasi yang mempengaruhi perubahan masyarakat tradisional menjadi masyarakat modern. ${ }^{8}$

Semua teori yang dikemukakan tersebut berisi nilai-nilai, sikap, pengetahuan, dan keterampilan yang kondusif untuk merubah sebuah masyarakat tradisional menjadi masyarakat modern yang mencerminkan tuntunan akan perlunya peninjuan dan perubahan sosial budaya, modernisasi dan pembangunan.

\section{B. Dampak Perubahan Sosial Terhadap Pendidikan}

Implikasi dari perubahan suatu sistem budaya yang dianut dalam masyarakat mengakibatkan terjadinya pengaruh yang signifikan terhadap nilainilai budaya tersebut dalam penyelenggaraan pendidikan secara nasional. Sistem pendidikan harus memperhatikan nilai-nilai budaya, karena budaya yang ada akan

${ }^{8}$ Soerjono, Sosiologi, h. 78 
datang menolong terjadinya pembudayaan dalam proses pendidikan yang diselenggarakan. ${ }^{9}$

Pendidikan merupakan sebuah bentuk dari perwujudan seni dan budaya manusia yang terus berubah, berkembang dan sebagai suatu alternatif yang paling rasional dan memungkinkan untuk melakukan suatu perubahan atau perkembangan. Sebagaimana telah dikemukakan sebelumnya bahwa perubahan sosial adalah perubahan yang terjadi pada struktur dan fungsi dalam sistem sosial, yang mana termasuk di dalamnya adalah pendidikan, sebab pendidikan ada di dalam masyarakat, baik itu pendidikan formal, informal maupun nonformal.

Pendidikan ada karena adanya suatu sistem masyarakat yang berperan di dalamnya, maka pendidikan dan masyarakat itu memiliki hubungan yang sangat erat dan saling ketergantungan. Oleh sebab itu pendidikan merupakan suatu bantuan yang didalamnya terdapat pengabdian masyarakat sehingga masyarakat itu semakin berkembang dan maju dengan adanya pendidikan, sebab pendidikan adalah sebuah proses pematangan dan pendewasaan masyarakat.

Pada zaman sekarang ini ada perubahan sosial yang berjalan dengan lamban, juga akan berdampak pada pendidikan, misalnya dengan bertambahnya jumlah penduduk yang cepat maka perlu disediakan sekolah untuk menampung siswa tersebut, sehingga sarana pendidikanpun sosial itu pula kebutuhan masyarakat terhadap pendidikan guna menghadapi kehidupan yang semakin kompleks sangat memerlukan pendidikan guna mempersiapkan masyarakat itu sendiri dalam menghadapi perkembangan zaman itu.

Upaya bangsa Indonesia untuk memberantas kebodohan dengan mewajibkan pendidikan dasar Sembilan tahun adalah upaya untuk mempersiapkan masyarakat dalam menghadapi perubahan-perubahan yang terjadi. Seiring dengan berubahnya pengetahuan dan keterampilan yang nantinya dapat digunakan atau dipraktikkan dalam kehidupan nyata, maka perubahan sosial sebagai akibat dari perubahan orientasi pendidikan juga akan terjadi.

Jika kita melihat perubahan sosial sebagai dampak dari berkembangnya teknologi adalah dengan sangat mudahnya mengakses internet bagi masyarakat yang tidak agamais dapat digunakan untuk hal-hal yang negatif, kita juga

${ }^{9}$ Ibid, h. 79 
menyaksikan banyak kecurangan-kecurangan, ketidakjujuran, dan banyak perbuatan negatif yang bertentangan dengan norma agama Islam sebagai dampak pada perubahan sosial karenanya sangat diperlukan sistem pendidikan yang dapat mempersiapkan manusia (masyarakat) untuk tidak melakukan perbuatan tersebut.

Dampak lain dari terjadinya perubahan sosial terhadap pendidikan adalah dengan terus dikembangkannya kurikulum yang mampu menjawab tantangan perubahan, juga dampak pada perubahan sistem manajemen pendidikan yang berorientasi pada mutu (quality oriented), yaitu akan peningkatan kualitas pembelajran unggul sehingga menghasilkan output yang berkualitas. ${ }^{10}$

Perubahan sosial yang terjadi pada suatu masyarakat sangat berpengaruh pada pendidikan, namun tidak semua perubahan sosial yang terjadi berdampak positif, tetapi ada juga perubahan sosial yang menghasilkan akibat buruk bagi dunia pendidikan, berikut sisi positif dan negatif dari suatu perubahan sosial terhadap pendidikan:

a. Dampak positif.

Sisi positif dari sebuah perubahan sosial bagi pendidikan adalah dapat meningkatkan taraf pendidikan dalam kehidupan masyarakat sehingga dapat menghasilkan manusia yang siap menghadapi perubahan sosial tersebut.

b. Dampak negatif

Sedangkan dampak negative dari suatu teknologi yang begitu pesat yang membuat banyak pengaruh budaya dari luar yang merasuk pada kehidupan dan cara hidup. Siaran televisi dan akses internet yang sudah biasa dilakukan dimana saja, menjadi tantangan tersendiri bagi dunia pendidikan untuk mengantisipasinya, jika tidak siap terhadap perubahan tersebut, maka siapapun akan tergusur, namun jika tidak maka para pegiat pendidikan senantiasa berinovasi dan berkreasi dalam mengantisipasi perubahan tersebut, dengan menggunakan fasilitas teknologi tersebut.

Pengaruh perubahan sosial yang lainnya terhadap pendidikan adalah terjadinya trasformasi pemikiran dalam pendidikan, seiring dengan perubahanperubahan sosial yang terjadi di dalam masyarakat, pendidikan juga mengalami

${ }^{10}$ Tirtosudarmo Riwanto, Dinamika Pendidikan dan Ketenagakerjaan Pemuda di Indosenia (Jakarta: Gramedia Widiasarma Indonesia, 1994), h. 78 
perubahan. ${ }^{11}$ Hal yang lebih konkrit dari pengaruh perubahan sosial terhadap pendidikan adalah ketika perubahan sosial membawa kepada perbaikan ekonomi masyarakat dan menuntut mereka akan memenuhi kebutuhan akan hasil teknologi, seperti: komputer/laptop, maka ketika seseorang anak yang mendapat tugas dari gurunya untuk membuat karya tulis sederhana yang bahannya tersedia lewat internet, maka secara langsung dan jelas dampak dan pengaruh adanya perubahan sosial.

Dengan melihat perkembangan lembaga pendidikan yang berorientasi pada IPTEK sebagai hasil dari berubahnya masyarakat, banyak visi sekolah yang mengedapankan orientasi IPTEK, karena disisi lain masyarakat juga menuntut lembaga pendidikan yang mengikuti perkembangan dan mampu mempersiapkan anak mereka untuk menghadapi masa depan. Jelaslah bahwa perubahan sosial yang terjadi sangat berdampak pada pendidikan.

\section{KESIMPULAN}

Dari uraian di atas, maka dikemukakan beberapa kesimpulan sebagai berikut, bahwa perubahan yang terjadi di masyarakat tentunya sangat berpengaruh pada dunia pendidikan. Masalah-masalah sosial pendidikan yang muncul di tengah masyarakat juga di alami dunia pendidikan. Sehingga sosiologi pendidikan memainkan perannya untuk ikut memformat pendidikan yang mampu berkiprah secara kontekstual. Sistem, muatan, proses, dana arah pendidikan perlu di tata ulang dan diatur secara khusus sehingga mampu menjawab sekaligus bermain di arena perubahan sosial budaya tersebut. Penggunaan alat dan sarana kebutuhan hidup yang modern telah memungkinkan pola piker dan sikap manusia untuk memproduk nilai-nilai baru sesuai dengan intensitas pengaruh teknologi terhadap tatanan kehidupan sosial budaya. Dalam hal ini, pendidikan menjadi instrument kekuatan sosial masyarakat untuk mengembangkan suatu sistem pembinaan anggota masyarakat yang relevan dengan tuntutan dan perubahan zaman.

${ }^{11}$ Syafaruddin dan Irawan Nasution, Manajemen Pembelajaran (Jakarta: Quantum Teaching, 2005), h. 13 


\section{DAFTAR PUSTAKA}

Soerjono Soekanto, Sosiologi Suatu Pengantar, cet. 5 (Jakarta: Raja Grafindo Persada, 2003), h. 304

Hasan Alwi, Kamus Besar Bahasa Indonesia, Jakarta: Balai Pustaka, 1990

David Berry, Pokok-Pokok Pikiran Dalam Sosiologi, Terj. Paulus Wirutomo, Jakarta: Raja Grafindo Persada, 2003

Tirtosudarmo Riwanto, Dinamika Pendidikan dan Ketenagakerjaan Pemuda di Indosenia, Jakarta: Gramedia Widiasarma Indonesia, 1994

Syafaruddin dan Irawan Nasution, Manajemen Pembelajaran, Jakarta: Quantum Teaching, 2005 